\title{
Neonatal outcome in pregnancies that presented premature rupture of membranes
}

\author{
Desfecho neonatal em gestações que evoluíram com amniorrexe prematura \\ Resultado neonatal en embarazos que llegaron a amniorrexe prematuro
}

Marcela Lima Silveira ${ }^{1}$, Náira de Oliveira Caminha ${ }^{1}$, Rosiléa Alves de Sousa ${ }^{1}$, Sarah Maria Fraxe Pessoa ${ }^{1}$, Eloah de Paula Pessoa Gurgel ${ }^{1}$, Dylmara Maria Prudêncio Cavalcante ${ }^{2}$

This study aimed to describe the neonatal outcomes of infants whose mothers had premature rupture of membranes during pregnancy. This is a retrospective, descriptive, quantitative study performed in a public maternity in Fortaleza-CE, Brazil, with 166 neonates of mothers with premature rupture of membranes, in 2010. Data were collected through research in medical records using a pre-structured form. There was a predominance of newborns at term with good birth weight and adequate vitality. Statistical analysis showed significant association between prematurity and prolonged latency and neonatal variables: need for respiratory support, neonatal infection and antibiotic use. It was concluded that gestational age has fundamental importance to conduct clinical management and prognostic evaluation of perinatal outcomes, as the main health problems related to premature rupture of membranes result from prematurity.

Descriptors: Fetal Membranes, Premature Rupture; Premature Birth; Morbidity.

Objetivou-se descrever os desfechos neonatais de recém-nascidos, cujas mães apresentaram amniorrexe prematura na gestação. Estudo descritivo, retrospectivo e quantitativo, desenvolvido em maternidade pública de Fortaleza-CE, Brasil, com 166 neonatos de mães com amniorrexe prematura, em 2010. Os dados foram coletados através de pesquisa aos prontuários, por meio de formulário pré-estruturado. Houve predominância de recém-nascidos a termo, com peso adequado e boa vitalidade ao nascer. A análise estatística mostrou associação significante entre prematuridade e período de latência prolongado e as variáveis neonatais: necessidade de suporte respiratório, infecção neonatal e uso de antibióticos. Concluise que a idade gestacional apresenta fundamental relevância para conduzir o manejo clínico e a avaliação prognóstica dos desfechos perinatais, visto que os principais agravos relacionados à amniorrexe prematura decorrem da prematuridade.

Descritores: Ruptura Prematura de Membranas Fetais; Nascimento Prematuro; Morbidade.

El objetivo fue describir los resultados neonatales de recién nacidos, cuyas madres tenían amniorrexe prematuro durante embarazo. Estudio descriptivo, retrospectivo y cuantitativo, en maternidad pública de Fortaleza-CE, Brasil, con 166 neonatos de madres con amniorrexe prematuro, en 2010. Los datos fueron recolectados mediante la búsqueda en registros médicos, uso de formulario pre estructurado. Predominaron recién nacidos a término, con peso adecuado y buena vitalidad al nacer. El análisis estadístico señaló asociación significativa entre prematuridad y latencia prolongada y las variables neonatales: necesidad de asistencia respiratoria, infección neonatal y uso de antibióticos. La edad gestacional presenta relevancia fundamental para llevar a cabo la gestión clínica y la evaluación de resultados perinatales, pues los principales problemas de salud relacionados con la amniorrexe prematuro son resultantes de la prematuridad.

Descriptores: Rotura Prematura de Membranas Fetales; Nacimiento Prematuro; Morbilidad.

\footnotetext{
${ }^{1}$ Universidade Federal do Ceará. Fortaleza, CE, Brazil.

${ }^{2}$ Faculdade Integrada do Ceará. Fortaleza, CE, Brazil.

Corresponding author: Sarah Maria Fraxe Pessoa

Av. Rui Barbosa, 3288 - Joaquim Távora. CEP: 60115-222. Fortaleza, CE, Brazil. E-mail: sarahfraxe2005@yahoo.com.br
} 


\section{Introduction}

Pregnancy is a physiological phenomenon and therefore in most cases its evolution occurs uneventfully: they are the so-called low-risk pregnancies. Other pregnancies, however, already start with problems or they develop during their course, with higher probability of unfavorable outcomes for both the mother and the fetus. This portion composes high risk pregnancies ${ }^{(1)}$, among which there are those that evolve with ruptured membranes.

The premature rupture of ovular membranes is an obstetric complication frequently detected in Brazilian maternities, culminating sometimes in longer hospital stays and higher hospital costs. It affects approximately $8-10 \%$ of all pregnancies and is present in one third of premature births, which contributes to a worse neonatal prognosis ${ }^{(2)}$.

This obstetric complication consists of the rupture of the membranes - amnion and chorion before the onset of labor, resulting in a loss of amniotic fluid. When this occurs before 37 weeks of gestation it is called Premature Rupture of Preterm Membranes. The time between the rupture of membranes and the onset of labor is defined as the latency period ${ }^{(3)}$. From this concept, one realizes that ruptured membranes affect both preterm pregnancies to term pregnancies, and childbirth may be premature or not, depending on how long the period of latency is.

The lower the gestational age is, the greater the latency period will be, due to expectant or not resolving conduct. Such conduct has the purpose of delaying labor and allows the fetus to reach the necessary lung maturity. However, the higher this latency period is, the greater the risk of infection for mothers and newborns will be. Therefore, newborns' prognosis worsens when the gestational age decreases and it becomes especially difficult when the premature rupture of membranes occurs before the 25th week of gestation $^{(4-5)}$.

However, the effect of prolonged latency on neonatal outcomes may be beneficial when the premature rupture of preterm membranes occurs in pregnancies below 34 weeks. This happens because it allows further development of the fetal systems and the use of antenatal corticosteroids and antibiotics, since immediate birth could lead to complications of prematurity, such as hyaline membrane syndrome, periventricular hemorrhage, and necrotizing enterocolitis ${ }^{(6-7)}$.

There are several risk factors associated with premature rupture of membranes, among which the maternal infections stand out (urinary tract, sexually transmitted and intrauterine infections), the cervicitis, the istmocervical incompetence and multiple pregnancies ${ }^{(8)}$.

From this perspective, premature rupture of membranes is considered an obstetric event that is included in high-risk pregnancies, whose etiology is poorly understood, diagnosis is difficult, maternal and fetal risks are significant, and its control is controversial ${ }^{(1,9)}$. It is worth noting that the concept of risk pregnancy brings an emotional charge of fear, insecurity, doubt and uncertainty to pregnant women, which mingle with the joy and hope for the life that is beginning ${ }^{(10)}$.

Given the importance of this topic, this study aimed to describe the neonatal outcomes of infants whose mothers had premature rupture of membranes during pregnancy. It is believed that from the identification of the most frequent neonatal outcomes in neonates, health professionals who assist them will be able to subsidize a more targeted assistance, helping to reduce the incidence of certain conditions and, consequently, decrease newborns' morbidity.

\section{Method}

This is a descriptive, retrospective study with a quantitative approach, developed in a public maternity in Fortaleza, Ceará, Brazil. It is an institution of tertiary health care and it is a reference in care for pregnant women in the state of Ceará, especially in high-risk pregnancies. It has 219 beds, out of which 
56 are used in the treatment of neonates of medium and high risk.

The sample consisted of all infants born in 2010, whose mothers were admitted with diagnosis of ruptured membranes in that institution. Such medical diagnosis was considered from the view of the amniotic fluid flowing through the external cervical hole proven by speculum examination.

Neonates from multiple pregnancies were not part of the sample, children of women who developed premature rupture of membranes during hospitalization and those who had other diseases associated.

Data were collected from mothers' and their newborns' medical records, which were filed in the department of medical archive of the institution. Out of the total of 250 records, 165 that met the criteria inclusion were studied. It is emphasized that each chart is equivalent to the set of records of the mother and her neonate, since the records of newborns is registered in the name of their mothers' and therefore they are filed together.

For data collection one used an instrument consisting of five parts: mother's identification and socioeconomic data; obstetric history; history of the current pregnancy; history of current hospitalization and data concerning the neonate.

Regarding the mother, the following variables were studied: age; origin; marital status; occupation; previous obstetric history; history of premature rupture of membranes and preterm birth; conduction of pre-natal and number of consultations; occurrence of urinary tractinfection, sexually transmitted infection and chorioamnionitis in pregnancy; latency period; drug therapy on admission and type of delivery. About the neonate, the variables studied were: gestational age; sex; birth weight; stature; Apgar score after five minutes of life; need for resuscitation in the delivery room; ventilatory support; drug therapy during hospitalization; occurrence of infection and neonatal death.

Among the neonatal variables for this study were considered as neonatal outcomes those that interfered in the baby's health, requiring therapeutic intervention. One highlights: the need for respiratory support; the use of medications during hospitalization (antibiotics, corticoids, surfactant) and the presence of neonatal infection.

Data were processed with the aid of the program Statistical Package for the Social Sciences, version 17.0. For analysis, one used descriptive statistics, through absolute and relative frequencies and statistical significance test to assess the association between the selected variables. It was considered as significant a value of p 0.05 and confidence interval of $95 \%$. Subsequently, the study was discussed in the light of the relevant literature.

The research project was submitted to the Ethics in Research Committee and approved under protocol number $102 / 11$. Because it is a study conducted in secondary sources, a Statement of Custodian was filled out, through which the responsibility for the records of the institution where the study was conducted gave authorization for the use of data contained there.

\section{Results}

Out of the 165 medical records of the mother/ son binomial admitted after maternal diagnosis of ruptured membranes, maternal age ranged between 14 and 46 years old, with $92.1 \%$ (152) of them between 15 and 35 years old. Most of them were from the capital, Fortaleza $(84.8 \%$ - 140), single (66\% - 109), and had as their occupation "housewife" $(49.7 \%$ - 82). As for the obstetric history, the greatest proportion was of multiparas (50.9\% - 84), and out of these $5.5 \%$ (9) had a history of premature rupture of membranes and $4.8 \%$ (8) of prematurity.

In the current pregnancy, $47.9 \%$ underwent at least six prenatal consultations. Regarding maternal infections, 31.5\% (52) presented urinary infections, $2.4 \%$ (4) had chorioamnionitis and $0.6 \%$ (1) a sexually transmitted infection. As to the management of premature rupture of membranes 
during hospitalization, $46.1 \%$ (76) of the women used antibiotics, $18.8 \%$ (31) used corticosteroids for fetal lung maturation and $73.9 \%$ (122) progressed to caesarean section. The latency period between rupture of membranes and delivery ranged from 2 hours to 24 days, and in $65.5 \%$ (108) was 24 hours, average $=42.62$ hours.

Table 1 shows the characterization of the neonates, as well as their birth conditions, in which it can be seen that $29.7 \%$ (49) of births were preterm (gestational age $<37$ weeks). It is noteworthy that the gestational age was assessed at birth by the Capurro method.

Table 1 - Characterization of newborns of mothers with premature rupture of membranes according to the data of birth $(n=165)$

\begin{tabular}{lc}
\hline Variables & $\mathbf{n}(\mathbf{\%})$ \\
\hline Sex & $80(48.4)$ \\
Female & $85(51.6)$ \\
Male & \\
Gestational age (weeks) & $2(1,2)$ \\
$<30$ & $17(10.3)$ \\
$30-34$ & $30(18.2)$ \\
$35-36$ & $116(70.3)$ \\
$37-41$ & \\
Birth weight (g) & $6(3.6)$ \\
$>3999$ & $127(77)$ \\
$2500-3999$ & $27(16.4)$ \\
1500 - 2499 & $5(3.0)$ \\
$\leq 1499$ & \\
Apgar score at 5 minutes & $2(1,2)$ \\
Severe asphyxia (0-3) & $6(3.6)$ \\
Moderate asphyxia (4-7) & $157(95.2)$ \\
Good vitality (8-10) & $7(4.2)$ \\
Need for resuscitation & $158(95.8)$ \\
Yes &
\end{tabular}

Table 2 presents interventions provided to newborns of mothers with admission diagnosis of ruptured membranes. It is noticed that the need to stay in the intensive care unit and the use of antibiotics for treatment or prophylaxis of neonatal infections are frequent.

Despite the high need for respiratory support, most neonates who used some form of oxygen therapy did so because of mild respiratory distress.
A newborn may have received one or more interventions for respiratory support. In 67.3\% (64) of the cases it was necessary only one type of support, in $22.1 \%$ (21) two types were used, in 6.3\% (6) three were required, $2.1 \%$ (2) used four and the same amount received five different kinds of respiratory support.

The majority of the sample showed no infections during the neonatal hospitalization, but in some cases prophylactic antibiotics were used because of the risk of infection by premature rupture of membranes and prolonged latency period.

The admission to the intensive care unit occurred in a small percentage of the cases, as well as the number of neonatal deaths. This fact has possibly happened due to the largest number of term births, which improves neonatal prognosis.

Table 2 - Respiratory interventions used in newborns of mothers with premature rupture of membranes

\begin{tabular}{|c|c|}
\hline Variables & n (\%) \\
\hline \multicolumn{2}{|c|}{ Interventions of respiratory support } \\
\hline Yes & $95(57.6)$ \\
\hline No & $70(42.4)$ \\
\hline \multicolumn{2}{|c|}{ Types of respiratory support * } \\
\hline Oxy-hood & $92(96.8)$ \\
\hline Handmade nasal CPAP** & $22(23.2)$ \\
\hline Mechanical ventilation & $8(8.4)$ \\
\hline Noninvasive ventilation & $4(4.2)$ \\
\hline Nasal cateter & $6(6.3)$ \\
\hline $\mathrm{O}_{2}$ in the incubator & $10(10.5)$ \\
\hline \multicolumn{2}{|l|}{ Neonatal infection } \\
\hline Yes & $31(18.8)$ \\
\hline No & $134(81.2)$ \\
\hline \multicolumn{2}{|l|}{ Antibiotics } \\
\hline Yes & $48(29.1)$ \\
\hline No & $117(70.9)$ \\
\hline \multicolumn{2}{|l|}{ Corticosteroid } \\
\hline Yes & $2(1,2)$ \\
\hline No & 163 (98.8) \\
\hline \multicolumn{2}{|l|}{ Surfactant } \\
\hline Yes & $6(3.6)$ \\
\hline No & $159(96.4)$ \\
\hline \multicolumn{2}{|l|}{ Neonatal death } \\
\hline Yes & $2(1,2)$ \\
\hline No & 163 (98.8) \\
\hline \multicolumn{2}{|c|}{ Admission to neonatal intensive care unit } \\
\hline Yes & $34(20.6)$ \\
\hline No & $131(79.4)$ \\
\hline
\end{tabular}


Table 3 - Relationship between gestational age at birth, maternal urinary tract infection during pregnancy, latency period and data about the hospitalization of infants of mothers with premature rupture of membranes $(n=165)$

\begin{tabular}{|c|c|c|c|c|c|c|c|c|c|}
\hline \multirow{3}{*}{ Variables } & \multicolumn{2}{|c|}{ Gestational age (weeks) } & \multirow[t]{2}{*}{$\mathbf{p}^{*}$} & \multicolumn{2}{|c|}{$\begin{array}{l}\text { Maternal urinary } \\
\text { tract infection }\end{array}$} & \multirow[t]{2}{*}{$\mathbf{p}^{*}$} & \multicolumn{2}{|c|}{$\begin{array}{l}\text { Latency period } \\
\text { (hours) }\end{array}$} & \multirow[t]{2}{*}{$\mathbf{p}^{*}$} \\
\hline & $<37$ & $\geq 37$ & & Yes & No & & $<24$ & $\geq 24$ & \\
\hline & $\mathrm{n}(\%)$ & $\mathrm{n}(\%)$ & & n (\%) & n (\%) & & n (\%) & $\mathrm{n}(\%)$ & \\
\hline \multicolumn{10}{|c|}{ Interventions of respiratory support } \\
\hline Yes & $43(45.3)$ & $52(54.7)$ & $<0.001$ & $30(31.6)$ & $65(68.4)$ & 0.984 & $51(53.7)$ & $44(46.3)$ & $<0.001$ \\
\hline No & $6(8.6)$ & $64(91.4)$ & & $22(31.4)$ & $48(68.6)$ & & $57(81.4)$ & $13(18.6)$ & \\
\hline \multicolumn{10}{|c|}{ Neonatal infection } \\
\hline Yes & $23(74.2)$ & $8(25.8)$ & $<0.001$ & $12(38.7)$ & $19(61.3)$ & 0.339 & $12(38.7)$ & $19(61.3)$ & 0.001 \\
\hline No & $26(19.4)$ & $108(80.6)$ & & $40(29.9)$ & $94(70.1)$ & & $96(71.6)$ & $38(28.4)$ & \\
\hline \multicolumn{10}{|c|}{ Antibiotic therapy in newborns } \\
\hline Yes & $30(62.5)$ & $18(37.5)$ & $<0.001$ & $17(35.4)$ & $31(64.6)$ & 0.490 & $17(35.4)$ & $31(64.6)$ & $<0.001$ \\
\hline No & $19(16.2)$ & 98 (83.8) & & 35 (29.9) & $82(70.1)$ & & $91(77.8)$ & $26(22.2)$ & \\
\hline
\end{tabular}

*Chi-square test. Confidence interval: $95 \%$

In table 3 there are the relations between the variables "gestational age", "maternal urinary infections" and "latency period" with neonatal outcomes of "need for respiratory support", "neonatal infection" and "antibiotic therapy in newborns".

One can therefore infer a statistically significant association between prematurity and prolonged latency with the above neonatal outcomes, which was not observed with maternal urinary infections.

\section{Discussion}

Despite the predominance of term births, it was observed that the occurrence of preterm births $(29.7 \%)$ found in this study is higher than the percentage of infants born alive in the general Brazilian population in 2010, which was of $7.1 \%$, demonstrating that premature rupture of membranes contributes to increase the occurrence of prematurity and its complications ${ }^{(11)}$.

A study conducted in China in the period from 2003 to 2007 showed an incidence of $11.2 \%$ of preterm births in pregnancies that progressed with ruptured membranes and a 9.8\% incidence of respiratory distress syndrome, and more than two thirds of these occurred in preterm infants, which shows a worse prognosis in cases of ruptured membranes that develop to a premature birth ${ }^{(12)}$.

A research developed in Santa Catarina only with pregnant women with premature rupture of ovular membranes in the period from 2007-2008 showed higher values than those found in our study in relation to the need for invasive mechanical ventilation (18.18\%), prolonged latency period $(86.35 \%)$ and diagnosis of neonatal infection (31.81\%), which strengthens the relationship between prematurity and increased neonatal morbidity and mortality ${ }^{(7)}$. In this sense, premature rupture of membranes can be listed as one of the obstetric risk factors for the occurrence of preterm delivery ${ }^{(13)}$.

In contrast, a survey conducted in two university centers in France, in the period from 2004 to 2006, showed no significant association between prematurity and the occurrence of neonatal infection $^{(2)}$.

Maternal infection may be the cause or 
consequence of premature rupture of membranes. Empirical antibiotic therapy has been used in developed countries to increase the latency period and reduce the risks of maternal and neonatal infection in cases of premature rupture of ovular membranes, thus, being an effective and inexpensive strategy to improve neonatal outcomes in developing countries. However, there is no consensus in the literature as to which antibiotic is the most appropriate in these cases $^{(14-15)}$.

The benefits of the use of prophylactic antibiotics on latency and neonatal morbidity and mortality were demonstrated by the study ${ }^{(16)}$ ORACLE, greatest work ever published about it, especially on the reduction of the incidence of hyaline membrane disease, need for surfactant treatment, infection and neonatal brain changes. What reinforces the need for antibiotic therapy for both the mother and the neonate, going with the findings of our study, which showed a higher number of newborns who used antibiotics (29.1\%) when compared to the number of cases of neonatal infection (18.8\%).

In this study, the bivariate analysis showed no significant relationship between the presence of maternal urinary tract infection and the neonatal outcomes "need for respiratory support", "neonatal infection" and "use of antibiotics for newborns".

However, it is recognized that the presence of premature rupture of membranes and urinary tract infection during pregnancy are risk factors for prematurity and neonatal infection, since bacteria are somehow related to the pathophysiology of rupture of membranes through production of substances and activation of inflammatory processes ${ }^{(6,17-18)}$.

A study conducted in Fortaleza with the aim of describing the use of antimicrobials in the neonatal intensive care unit showed that the premature rupture of membranes was the condition that mostly caused antibiotics' use by hospitalized newborns ${ }^{(19)}$.

It is known that the infection rate is directly proportional to the duration of the latency period, being higher after the first 24 hours of ruptured membranes ${ }^{(6)}$. Therefore, it is possible that the maternal urinary tract infection did not show statistically significant relationship in the bivariate analysis in table 3 , due to the predominance in this study of the latency period of less than 24 hours.

The management of pregnancies that develop with premature rupture of membranes depends on the gestational age at which it occurs. While in pregnancies below 24 weeks the prognosis is poor, and in many cases the termination of pregnancy is indicated, above this age, neonatal prognosis improves, as therapeutic resources increase, including prophylactic antibiotics and steroids therapies ${ }^{(5)}$.

It is interesting to mention that a systematic review conducted in the United States found no increase in neonatal morbidity and mortality in cases of active management (shorter latency) compared to conservative treatment (prolonged latency) in pregnancies below 37 weeks ${ }^{(20)}$.

Conditions at birth are factors that strongly influence the adaptation and evolution of postnatal life and the diagnosis of prematurity is the one that contributes the most to the increase of hospitalizations in high-risk neonatal units, submitting newborns to increasingly specialized treatments in order to survive. Thus, the conditions that favor the occurrence of preterm delivery should be constantly studied and prevented, since prematurity is among the leading causes of perinatal morbidity and mortality, accounting for $75 \%$ of perinatal deaths ${ }^{(21)}$.

\section{Conclusion}

It is concluded that the most frequent neonatal outcomes in pregnancies with premature rupture of membranes are: prematurity, need for respiratory support because of mild respiratory discomfort, prophylactic antibacterial medication or therapy for neonatal infection and hospitalization in the neonatal intensive care unit.

However it is emphasized that prematurity is the main cause of neonatal damage between pregnancies 
that have complications such as premature rupture of membranes, since newborns of term pregnancies have little or no adverse outcomes. Despite numerous scientific and technological advances in healthcare, the complications of prematurity still present major challenges for Obstetrics and Neonatology, since the number of premature births is still quite significant and the consequences in the short and long term for these neonates and their families are immeasurable.

In this sense, it is essential an action directed at the prevention and treatment of harms that are closely related to the occurrence of premature rupture of membranes and consequently to premature labor.

It is noteworthy that the present study has limitations because it is a survey based on secondary sources, depending strictly on professional registry of patients' records.

Therefore, it is suggested the conduction of future studies on this subject in order to understand the various facets of this problem and its real impact on the population, providing a basis for a better performance of the various health fields in this area.

\section{Collaborations}

Silveira ML and Caminha NO contributed to the conception of the study, data collection, analysis, interpretation of data and drafting of the article. Sousa RA contributed to the conception of the study, drafting of the article and final approval of the version to be published. Pessoa SMF contributed to the writing of the article and final approval of the version to be published. Gurgel EPP contributed to the writing of the article. Cavalcante DMP contributed to the data collection.

\section{References}

1. Versiani CC, Fernandes LL. Gestantes de alto risco internadas na maternidade de um hospital universitário. Rev Norte Min Enferm. 2012; 1(1):68-78.
2. Popowski T, Goffinet F, Maillard F, Schmitz T, Leroy S, Kayem G. Maternal markers for detecting earlyonset neonatal infection and chorioamnionitis in cases of premature rupture of membranes at or after 34 weeks of gestation: a two-center prospective study. BMC Pregnancy Childbirth. 2011; 11:26.

3. Federação Brasileira das Associações de Ginecologia e Obstetrícia. Manual de perinatologia. São Paulo: FEBRASCO; 2013.

4. Azria E, Anselem O, Schmitz T, Tsatsaris V, Senat M, Goffinet F. Comparison of perinatal outcome after pre-viable preterm prelabour rupture of membranes in two centers with different rates of termination of pregnancy. BJOG. 2012; 119(4):449-57.

5. Strevens H, Allen K, Thornton JG. Management of premature prelabor rupture of the membranes. Ann N Y Acad Sci. 2010; 1205:123-9.

6. Corredor MLP, Miranda LR, Domínguez RA. Caracterización de los resultados perinatales en recién nacidos de mujeres con ruptura prematura de membranas entre las semanas 28 y 34 de gestación en la Clínica de Maternidad Rafael Calvo, Cartagena, en el período de diciembre de 2010 a mayo del 2011. Espiga Científica. 2012; 9(1):3143.

7. Gonçalves LF, Silveira SK, Saab Neto JA. Estudo descritivo sobre a antibioticoprofilaxia na ruptura prematura pré-termo de membranas. Arq Catarin Med. 2009; 38(2):67-72.

8. Sandes TJA, Araújo VMG, Vasconcelos FBL. Assistência de enfermagem à gestante portadora de ruptura prematura das membranas ovulares. In: Santos LGA, Andreto LM, Figueira MCS, Morimura MCR, Germano EM, Melo EMVB. Enfermagem em ginecologia e obstetrícia. Rio de Janeiro: Medbook; 2010. p. 215-7.

9. Costa MC, Bezerra Filho JG, Andrade Bezerra MG, Veríssimo de Oliveira MI, Carvalho de Oliveira RM, De Vasconcelos Silva AR. Gestação de risco: percepção e sentimentos das gestantes com amniorrexe prematura. Enferm Glob. 2010; (20):1-11.

10. Oliveira VJ, Madeira AMF, Penna CMM. Vivenciando a gravidez de alto risco entre a luz e a escuridão. Rev Rene. 2011; 12(1):49-56. 
11. Ministério da Saúde (BR). Coordenação Geral de Informações e Análise Epidemiológica, Secretaria de Vigilância em Saúde. Consolidação do sistema de informação dos nascidos vivos - 2011. Brasília: CGIAE; 2013.

12. Liu J, Feng ZC, Wu J. The incidence rate of premature rupture of membranes and its influence on fetalneonatal health: a report from Mainland China. J Trop Pediatr. 2010; 56(1):36-42.

13. Zugaib M. Obstetrícia. $2^{\underline{a}}$ ed. São Paulo: Manole; 2012.

14. Cousens S, Blencowe H, Gravett M, Lawn JE. Antibiotics for pré-term pré-labour rupture of membranes: prevention of neonatal deaths due to complications of pré-term birth and infection. Int J Epidemiol. 2010; 39:134-43.

15. Kenyon S, Boulvain M, Neilson JP. Antibiotics for preterm rupture of membranes. Cochrane Database Syst Rev. 2013; 12(3):1-18.

16. Kenyon SL, Taylor DJ, Tarnow-Mordi W. Broadspectrum antibiotics for preterm, prelabour rupture of fetal membranes: the ORACLE 1 randomised trial. Lancet. 2001; 357:979-88.

17. Rodríguez-Coutiño SI, Ramos-González R, Hernández-Herrera RJ. Factores de riesgo para la prematurez. Estudio de casos y controles. Ginecol Obstet Mex. 2013; 81(9):499-503.

18. Nomura ML, Passini Júnior R, Oliveira UM, Calil R. Colonização materna e neonatal por estreptococo do grupo B em situações de ruptura pré-termo de membranas e no trabalho de parto prematuro. Rev Bras Ginecol Obstet. 2009; 31(8):397-403.

19. Chaves EMC, Lima NM, Dias KCF, Aragão MMS, Almeida PC, Vasconcelos SMM. Uso de antimicrobianos em uma unidade de terapia intensiva neonatal em Fortaleza. Pediatr Mod. 2012; 48(8):121-5.

20. Buchanan SL, Crowther CA, Levett KM, Middleton P, Morris J. Planned early birth versus expectant management for women with preterm prelabour rupture of membranes prior to 37 weeks' gestation for improving pregnancy outcome. Cochrane Database Syst Rev. 2010; 17(3):1-17.

21. Oliveira MMC, Almeida PC, Cardoso MVLML. Growth of premature children with very low weight coming from the neonatal unit - a descriptive study. Online Braz J Nurs [serial on the Internet]. 2009 [cited 2012 July 29];8(1): Available from: http:// www.objnursing.uff.br/index.php/nursing/ article/view/j.1676-4285.2009.2256/472 